\title{
Determinants of Entrepreneurial Intention of Tarcha Industrial College Students of Dawro Zone
}

\author{
Samuel Batisa \\ Department of Management, Wolaita Sodo University,Ethiopia
}

\begin{abstract}
The main objective for this study is to understand how personality trait, social norm financial access, education and training, and government administration affect entrepreneurial intention of college students. Five departments were purposively selected and Stratified sampling technique was employed to draw sample from population for this particular study. The quantitative and qualitative approaches were employed as research design. The study was used both primary and secondary data. The primary data for this study was gathered by distributing 238 survey questionnaires and 226 questionnaires were returned by sample respondents from total number of 590 population of selected TVET Colleges of Dawro Zone, (Tercha industrial College,). The collected data were analyzed through descriptive statistics, correlation analysis and multiple regressions. The multiple regression result shows that personality trait, social norm, education and training, financial access and government administration were significantly influence entrepreneurial intention whereas, social norm have no significant relationship with entrepreneurial intention. The finding specifically imply that TVET Colleges are advised to give attention to the impact of educational and training influences and identify the way to enhance students confidence to perform entrepreneurial roles through development of entrepreneurship center and methods of teaching to guides and encourage students to pursue their own ideas. Finally, Ethiopian ministry of education, TVET Agency is expected to look at TVET Competence to improve entrepreneurial intention of the students.
\end{abstract}

Keywords: Entrepreneurial intention, Determinants, Personality trait, Social norm, Education and training, financial access and Government administration.

DOI: $10.7176 / \mathrm{EJBM} / 11-34-04$

Publication date: December $31^{\text {st }} 2019$

\section{Justification}

The world now more than ever before needs individuals with distinguished capacities to develop new products, new process and revolutionizing market radically. It is people with distinguished characters that will develop the capacity to continuously tackle complex economic tasks that seem to have no obvious or immediate solutions (Mazzarol, Voley, Doss \& Thein 1999). ). This development of events has put entrepreneurship in the limelight. Iacobucci and Micozzi (2012) argue that entrepreneurship education plays a significant role in promoting the spirit of entrepreneurship among students. Students who have attended entrepreneurship courses are more likely to start their own business than those who haven't (Packham et al., 2010). Entrepreneurship education, especially in scientific and technological universities, is crucial to enhance entrepreneurs' innovation skills in a dynamic environment (Menzies and Paradi, 2003).

Despite the importance of entrepreneurship education, the link between education, training, student's intention to set up a new firm and making entrepreneurship as their career is a complex and under-investigated process Nabi and Holden (2008). Entrepreneurship has also been found as a great significant engine of economic growth, productivity and social development; but academicians, practitioners and policymakers recognized its importance recently. People who are working as an entrepreneur reported that great benefits including freedom in decision making, higher self-esteem, challenge and greater sense of control (Nickels, McHugh and McHugh, 2010). Bakotic and Kruzic (2010) noted that the entrepreneurship promotion has become one of the main issues in public policy of the most of industrial countries. According to this context, well-educated entrepreneurs are top priority.

In Ethiopia the establishment of micro and small enterprises serves as the base for entrepreneurship development. Based on these facts, the development of micro and small enterprises becomes a special focus of the current government of Ethiopia, given that they comprise the largest share of total enterprises and employment in the non-agricultural sectors. As a result the government created a favorable environment for young people to organize themselves and engage in business activities to supply inputs for the government owned projects. Besides, in recognition of the important role of MSEs have to play in creating income, employment opportunities and in reducing poverty, the government drafted its first MSEs Development Strategy in 1997. Entrepreneurship is the major driving engine of many nations' economic growth, innovation and competitiveness (Scarborough \& Zimmerer, 2003; Kuratko \& Hodgetts, 2004). Realizing the importance of entrepreneurship for social and economic development of Ethiopia, entrepreneurship is a topic requiring a lot of attention from academicians, researchers and policy makers. Intention towards entrepreneurship is commonly associated with several personal characteristics (values and attitudes, personal goals, creativity, risk-taking propensity and locus of control) that might be expected to be influenced by a formal program of education. Education also serves as a preparatory 
function in relation to new venture creation, transferring of knowledge and the relevant skills that increase the selfefficacy (Bandura, 1986) and effectiveness of the potential entrepreneur.

For the unemployment issues among TVET students serious concern has been raised by policy makers and academicians. In addressing the issue, these students can choose to be self-employed rather than searching for a job. Many TVET trainees do possess the skill, knowledge and attitudes that are important for starting-up their own business, however, only a tiny percentage of trainees choose to be self-employed immediately after complete different levels of TVET program. It may be due to lack of self-confidence, lack of encouragement or reassurance. As becoming entrepreneurs, their intentions on becoming self-employed have prompted researcher to investigate particularly on the influence of entrepreneurial characteristics and entrepreneurial intention among TVET students towards entrepreneurial activities.

In general, entrepreneurial intention is defined as a state of mind that leading an individual's attention and action toward the endorsement of entrepreneurial behavior, building new business concept and undertaking in entrepreneurial career. It is important for students to know that entrepreneurship is an available career option for them and understand their interest and intention towards entrepreneurial career.

Entrepreneurship has becoming an important issue in recent years due to its contribution to national economy development and society at large. Decisions to be entrepreneurs are determined by certain factors and it is a planned behavior instead of engaging it accidentally. Thus, underlying factors that influence students' intention towards entrepreneurial career are vital. Therefore, this study seeks to investigate the impact of personality trait, social norm, education and training, financial access and government administration factors on the entrepreneurial intention of students in TVET Colleges.

We are in an age where the entrepreneurial culture should flourish to the extent that entrepreneurship needs to be regarded as a career that is desirable to every individual. It is within this framework that a proposition is made that students and especially College students, form a significant portion of potential entrepreneurs.

Currently, there are a number of studies conducted on students' entrepreneurial intentions, but most of the previous studies are specific wise which have focused on a particular group of students in the line of age, gender, faculty, and specialty such as Business, engineering students etc, final year of University students and a number of other categorization. In addition, there were no studies conducted on entrepreneurial intention of TVET College students' and also in Dawro Zone. After understanding the well-known gaps, the researcher felt a need to combine all these categorizations and targeted on the selected TVET College in Dawro Zone. So, in this investigation the student researcher fill this gap by conducting research on the determination of entrepreneurial intention factors of TVET College students to measure by personality trait, Social norm, Education and training, Financial access, and Government administration factors.

\section{Literature Review}

\subsection{Entrepreneurship Development in Ethiopia}

Development of micro and small enterprises becomes a special focus of the current government of Ethiopia, given that they comprise the largest share of total enterprises and employment in the non-agricultural sectors. As a result the governments created a favorable environment for young people to organize themselves and engage in business activities to supply inputs for the government owned projects. Besides, in recognition of the important role MSEs have to play in creating income, employment opportunities and in reducing poverty, the government drafted its first MSEs development Strategy in 1997.

According to Gebrehiwot and Wolday, 2004 Ethiopia's MSEs are deal with many problems, which have a negative impact on the utilization of the sector for economic development and poverty reduction. It is obvious these problems will be more challenging for the young who have less experience and knowledge about how to handle them.

However, unlike the other countries, which have the experience of youth entrepreneurship development, Ethiopia lacks an institution or organization working specifically on youth entrepreneurship development.

Concerning the empirical research of entrepreneurship development in Ethiopia; most of the researches were focused on concepts and definitions of entrepreneurship development. Some of the researches also focused on enterprise scanning and general assessment of MSEs in Ethiopia. For example an investigation made by Andualem T. (1997), mainly focuses on concepts and definitions of entrepreneurship development. This research indicated that the overall socio-cultural and economic environment of the country is not conducive to entrepreneurship development. As a result he suggested that the general entrepreneurship environment should be crafted to be conducive to the development of MSEs and entrepreneurship. The research has also recommended for the establishment of appropriate institutions and facilities to enhance entrepreneurship. Many specific research studies were also undertaken in the country in relation to entrepreneurship development in MSEs. For instance, Fekadu and Daniel (1997) focused on the access to finance for MSEs and they found out that the credit facility for MSEs in the country is very poor and it requires more attention for the development of the sector. Adugna (1997) also studied the influence of policy in the development of MSEs and the result of the study indicated the existence of 
structural problems in the sector such as concentration of outputs, technologies and infrastructure facilities.

\subsection{TVET Objectives in Ethiopia}

One of the most important features of TVET is its orientation towards the world of work and the emphasis of the curriculum on the acquisition of employable skills. TVET delivery systems are well placed to train the skilled and entrepreneurial workforce that needs to create wealth and emerge out of poverty. . According to Africa Union (2007), another important aspect of TVET is that it can be delivered at different levels of sophistication. This means TVET institutions can respond to the different training needs of learners from different socioeconomic and academic backgrounds, and prepare them for gainful employment and sustainable livelihoods. In Ethiopia, TVET was the most neglected area in the history of the education system. However, following 2000/01 a massive expansion of this sub-sector has been operational. The strategic thinking behind the expansion of the TVET subsector is to meet the middle level human power needs of the economy which has become very essential to the overall development of the country (MOE, 2002). The goal of the TVET system is to create a competent, capable and adaptable workforce to economic and social developments in Ethiopia, and to enable an increasing number of Ethiopians to find gainful employment and self-employment in the different economic sectors of the country (Engineering Capacity Building Program, 2006). To this end, TVET will be re-organized into an outcome-based system. This means that identified competencies needed in the labor market become the final benchmarks of training and learning, and that all institutions, rules and regulations of the TVET system will be re-defined so that they support Ethiopians to become competent. According to MOFED report of (2000) edition, the economic policy and strategy of Ethiopia requires technical and professional skills in broad and specific occupational fields. It is with this intention that the Government of Ethiopia has put in place a comprehensive capacity building development program aimed at strengthening its human resource potential through TVET programs. To meet this demand, public and private TVET institutions have increased in number. Moreover, the training areas have been diversified, and enrolment has also increased. Graduates of TVET institutes/colleges will not only be government or private sector employees, but they are also expected to be self-employed citizens. To this end, courses in entrepreneurship development would be offered to trainees so that they don't only have the professional skills, but also the ability to create their own self-employment opportunities MOE (2002). According to this document, this action was considered as one of the major actions intended to achieve the skilled man power requirements of the economy.

\subsection{Entrepreneurial Intention}

Entrepreneurial intention is the entrepreneur's states of mind that direct attention, experience, and actions towards a business concept (Bird, 1988). Intentions are considered to be the very important step in the entrepreneurship process for people who want to start up a new business. Creating a new business is composed of conscious activities so that the individual fosters primary idea of a business develops the plan in a secure environment and implements the business program with practical actions (Krueger et al, 2000).

According to Bandura (2001), an intention is a representation of a future course of action to be performed; it is not simply an expectation of future action but a proactive commitment to bringing about. An intention is the center of the plan of action. This means that, absent intention, action is unlikely. An entrepreneurial intention is a commitment to starting a new business. It is the degree of commitment directed towards the performance of the entrepreneurial endeavor of putting up a business for self-employment (Krueger, 1993).

According to Matthews and Moser (1995), study on business administration university students found that gender and families which own business influenced entrepreneurial attitudes among the students. Clark et .al (1984), surveyed on the students participated in introductory entrepreneurship course and found that, by the end of the course, $80 \%$ of the students are intend to start their own business and from which $76 \%$ students are speak out that attending the course had strong influence on their decision to enter the entrepreneurial career.

According to Norudin et.al (2007), the correlation between the willingness of the students to be an entrepreneur with the financial factor is very much significant.

\subsection{Hypothesis}

$\mathbf{H}_{1}$; Personality trait has a significant impact on TVET students' entrepreneurial intentions

$\mathbf{H}_{2}$; Social norm has a significant impact on TVET students' entrepreneurial intentions

$\mathbf{H}_{3}$; Access to finance has a significant effect on TVET students' entrepreneurial intentions

$\mathbf{H}_{4}$; Education and trainings has a significant impact on TVET students' entrepreneurial intentions.

H5 Government administration has a significant effect on TVET students' entrepreneurial intentions.

\section{Methodology}

In order to attain objectives of the study, a qualitative and quantitative approach has been employed. The research 
is a cross-sectional study; aimed at collecting data at one point in time and describing the study population rather than indicating the pattern of change which might be witnessed over time. Data for the study came from both primary and secondary sources. Primary information was collected by well-designed questionnaire as its primary instrument. It was completed by the students of Tercha industry colleges. Secondary data were obtained from internet, and published or non-published documents. Both purposive and stratified sampling techniques were employed to select the department and sample from students respectively with a total sample size of 226. A survey questionnaire was prepared using five point Likert scale( $1=$ strongly dis agree, $5=$ strongly agree) to measure the response on continuous scale. Pilot study was conducted on 30 college students to check the reliability and validity of the questionnaire. Reliability test was done by using cronbanch alpha to understand how closely the set of items are related as a group or factors. The cronbach alpha of various factors ranges from 0.82 to .91 which indicates that the questionnaire is highly reliable. Validity of the questionnaire was ensured by dissing with corporate managers and academicians from the university. Multiple linear regression and Pearson's product moment correlation coefficient was used to determine the relationship between independent variables and dependent variable.

\section{DATA ANALYSIS CONCLUSION, RECOMMENDATION}

\subsection{Personality trait factors}

Table: 4.1: Personality trait factors

\begin{tabular}{|c|c|c|c|c|}
\hline & Personality trait & $\mathrm{N}$ & Mean & $\begin{array}{c}\text { Std. } \\
\text { Deviation }\end{array}$ \\
\hline 1. & $\begin{array}{l}\text { I am confident that I would succeed if I started my own business (Self } \\
\text { Confidence) }\end{array}$ & 226 & 3.16 & .049 \\
\hline 2. & I can take calculated Risk to start my own business (calculated risk taker) & 226 & 3.32 & .050 \\
\hline 3. & $\begin{array}{l}\text { I believe that constructive feedback has a great role on business success } \\
\text { (Responsive to feedback) }\end{array}$ & 226 & 3.19 & .051 \\
\hline 4. & $\begin{array}{l}\text { I believe that exercising good leadership is contributing to business success } \\
\text { (Dynamic leader) }\end{array}$ & 226 & 3.25 & .052 \\
\hline 5. & $\begin{array}{l}\text { I believe that I will start a new business or I will do an existing business } \\
\text { in a new ways (Innovative and creativity) }\end{array}$ & 226 & 3.43 & .050 \\
\hline 6. & $\begin{array}{l}\text { I have initiative to work, taking the lead rather than waiting for others } \\
\text { ( initiative Taking) }\end{array}$ & 226 & 3.62 & .059 \\
\hline 7. & $\begin{array}{l}\text { Starting my own business sounds attractive to become hard worker (Hard } \\
\text { working) }\end{array}$ & 226 & 3.41 & .050 \\
\hline 8. & $\begin{array}{l}\text { I am the best at identifying opportunities Sees and Acts on Opportunities } \\
\text { (Opportunities seeking) }\end{array}$ & 226 & 3.08 & .056 \\
\hline 9. & I am highly motivated to start my own business. (Highly motivated) & 226 & 3.28 & .052 \\
\hline 10. & I must do well to make my business Profitable. (Profit-oriented). & 226 & 3.45 & .061 \\
\hline 11. & Grand Mean & & 3.32 & \\
\hline
\end{tabular}

Source: Survey of 2017

As shown in table 4.1 above, personality trait factors listed as likert-scale has their own effect on the entrepreneurial intention of students by relying on the value of mean taken from the respondents' response. An indicator with higher mean value affects the entrepreneurial intention of students. The personality trait initiative taking (3.62), profit-oriented trait (3.45), innovative and creativity (3.43), hardworking (3.41) have a higher mean value from weighted means they have highly affect the entrepreneurial intention of students. Indicators like opportunities seeking, self-confidence, responsive to feedback, dynamic leader and highly motivated had relatively less impact on growth of students entrepreneurial intention, implies that they have lower mean values from the weighted means. The result is particularly consistent and supported by previous researchers (Zain et al., 2010; Costa \& McCrae, 1984) which supported that personality traits has positive impact on stimulating students' entrepreneurial intention. 


\subsection{Social Norm}

Table 4.2: - Social norm

\begin{tabular}{|c|c|c|c|}
\hline & $\mathbf{N}$ & Mean & $\begin{array}{c}\text { Std. } \\
\text { Deviation }\end{array}$ \\
\hline $\begin{array}{l}\text { I believe that my closest family members think that I should pursue a } \\
\text { career as an entrepreneur }\end{array}$ & 226 & 3.08 & 1.136 \\
\hline $\begin{array}{l}\text { I believe that my closest friends think that I should pursue a career as an } \\
\text { entrepreneur }\end{array}$ & 226 & 2.49 & .925 \\
\hline $\begin{array}{l}\text { I believe that people, who are important to me, think that I should pursue } \\
\text { a career as an entrepreneur }\end{array}$ & 226 & 2.87 & .866 \\
\hline Those start businesses should be appreciated by the society & 226 & 2.81 & .984 \\
\hline \multirow{2}{*}{$\begin{array}{l}\text { Most of the wealth in a society or nation is created by individuals who } \\
\text { founded firms } \\
\text { Weighted mean }\end{array}$} & 226 & 3.27 & 1.027 \\
\hline & & 2.90 & \\
\hline
\end{tabular}

Source: Survey 2017

Responses to items checking the extent of social norm related factors on Tercha industrial college student entrepreneurial intention have been given in the table 4.2. By concerning their mean value of the indictors wealth is created by individuals have mean value of (3.27) and closest family member think as entrepreneur have a higher impact on students entrepreneurial intentions. Thinking people who as career and appreciation of society on starting new business have a moderate effect on student's intentions. While closest friend think have a less impact on the student's entrepreneurial intention concepts. This implies that the pressure exerted to the trainees from society is relatively high. Society exerts pressure to their children to pursue entrepreneurship as their future career choice and the society is the significant influential of the entrepreneurial intention. The more supportive the social norms are, the higher the intention (Wilson, Kickul and Marlino, 2007).

\subsection{Educational and Training}

Table 4.3: Entrepreneurship Education and Training

\begin{tabular}{|c|l|c|c|c|}
\hline & Entrepreneurship Education and Training & $\mathrm{N}$ & Mean & $\begin{array}{c}\text { Std. } \\
\text { Deviation }\end{array}$ \\
\hline 1. & Entrepreneurship course should be compulsory in the college. & 226 & 2.85 & .894 \\
\hline 2. & $\begin{array}{l}\text { Entrepreneurship subject is very important in thinking my own } \\
\text { business }\end{array}$ & 226 & 2.76 & .762 \\
\hline 3. & Entrepreneurship should be train in College by Business Teachers. & 226 & 2.82 & .868 \\
\hline 4. & The course had provided enough knowledge to be an entrepreneur & 226 & 2.72 & 1.002 \\
\hline 5. & $\begin{array}{l}\text { Quality of teaching entrepreneurship highly affected my practical } \\
\text { skills on starting my own venture. }\end{array}$ & 226 & 2.54 & .945 \\
\hline 6. & I have deep knowledge on Writing a Business Planning & 226 & 2.05 & .668 \\
\hline 7. & I have deep knowledge on Idea development & 226 & 2.64 & .829 \\
\hline 8. & I have deep knowledge on Idea screening. & 226 & 2.05 & .668 \\
\hline 9. & $\begin{array}{l}\text { Do you think that the course had exposed you to basic skills } \\
\text { required for entrepreneur? }\end{array}$ & 226 & 2.56 & .887 \\
\hline 10. & I want to start my own business after finishing the training & 226 & 2.69 & .959 \\
\hline 11. & Grand mean & & 2.568 & \\
\hline
\end{tabular}

Source: Survey 2017

According to the results in table 4.3 respondents were asked 10 questions concerning to entrepreneurial education support. The overall weighted mean for entrepreneurship education support issues was about 2.568 that mean the majority of respondents approved that education and trainings were good for entrepreneurial intention developments. But specifically from the above data it can be observe and the needs for knowledge on idea screening and business plan writing know how was not clearly understood by students with mean value of 2.05 which shows doubt of respondents. 


\subsection{Perceived Access to Finance}

Table 4.4:- Perceived access to Finance

\begin{tabular}{llcc}
\hline \multicolumn{1}{c}{ Items } & N & $\begin{array}{c}\text { Mean } \\
\text { Standard } \\
\text { deviation }\end{array}$ \\
\hline \hline It is easy to obtain startup capital in your areas & 226 & 2.05 & .668 \\
\hline \hline Banks are ready to give credit for new business in your areas & 226 & 2.44 & 1.037 \\
\hline \hline $\begin{array}{l}\text { It is easy to start one's own business due to the availability of financial } \\
\text { resources. }\end{array}$ & 226 & 2.47 & .921 \\
\hline \hline Financial institutions are ready to give required finance to start business. & 226 & 2.49 & .795 \\
\hline \hline It is easy to get financial institution in your area & 226 & 2.34 & .853 \\
\hline \hline Personal savings is the simplest form of starting capital for a new business. & 226 & 2.67 & .983 \\
\hline \hline Debt - borrowing from a lender better to start a new business & 226 & 2.62 & 1.154 \\
\hline \hline It is easy to get initial capital from Family \& Friends Financing. & 226 & 2.56 & 1.002 \\
\hline \hline I can get 20\% of start-up capital from personal saving. & 226 & 2.63 & 1.162 \\
\hline \hline I believe that I can get 80\% start-up capital from micro finance loan. & 226 & 2.51 & .962 \\
\hline \hline Weighted Mean & 2.48 \\
\hline SOur
\end{tabular}

\section{Source: Survey 2017}

Regarding to perceived access to finance observed that respondents were negatively responded towards access to finance in promoting entrepreneurial intention in Tercha TVET colleges with a weighted mean of 2.48 which indicate certainty of the respondent about the impact of access to finance to develop entrepreneurial intention of trainees. There was no access to finance for starting new business as it was perceived by respondents. The findings of this study were in line with Grilo and Thurik (2005), financial constraints have a negative impact on the decision to become an entrepreneur, and lack of financial support is an obstacle to start a new business which has direct effect on the fact of being self-employed.

\subsection{Perceived Government Administration}

Table 4.5: Perceived government administration

\begin{tabular}{|c|c|c|c|}
\hline Perceived government administration & $\mathrm{N}$ & Mean & $\begin{array}{l}\text { Standard } \\
\text { deviation }\end{array}$ \\
\hline There are sufficient subsidies available for new business in Ethiopia & 226 & 2.06 & .786 \\
\hline The procedures for establishing a new business are Clear & 226 & 2.17 & .675 \\
\hline Government policy is favorable to start a new business. & 226 & 2.28 & .872 \\
\hline Government rule and regulations are good to start and run a business. & 226 & 2.29 & .945 \\
\hline Government bureaucracy is clear for traders. & 226 & 2.06 & .786 \\
\hline Government motivates business owners to promote entrepreneurial activity. & 226 & 2.56 & 1.002 \\
\hline $\begin{array}{l}\text { It is easy to start one's own business due to the simplicity of the administrative } \\
\text { procedure. }\end{array}$ & 226 & 2.53 & .973 \\
\hline The government exempt business taxes for new business & 226 & 2.62 & 1.154 \\
\hline There is a work place provided by Government to initiate new business & 226 & 2.56 & 1.002 \\
\hline Government provides the necessary infrastructure for business owners. & 226 & 2.67 & 1.163 \\
\hline Weighted Mean & & 2.38 & \\
\hline
\end{tabular}

Source: Survey 2017

The above table (4.5) shows that the mean score of perceived government administration is below midpoint of likert scale which is 2.38. This means that the government administration is not favorable for new business formation as it was perceived by respondents. The perception of students towards government administration regarding to entrepreneurship was found negative. 


\subsection{Correlation Analysis}

Table 4.6: Correlation between independent and dependent variables

\begin{tabular}{|c|c|c|c|c|c|c|c|}
\hline & & 1 & 2 & 3 & 4 & 5 & 6 \\
\hline 1 & Entrepreneurial intention & 1 & & & & & \\
\hline 2 & Personality trait factor & .072 & 1 & & & & \\
\hline 3 & Social norm & $.485 * *$ & .029 & 1 & & & \\
\hline 4 & Educational and Training & $.527 * *$ & .051 & $.640 * *$ & 1 & & \\
\hline$\overline{5}$ & Access to finance & $.465 * *$ & (.138* & $.383 * *$ & $.656 * *$ & 1 & \\
\hline 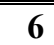 & "Government Administration & $.762 * *$ & $.106^{*}$ & $.675 * *$ & $.758 * *$ & $.591 * *$ & 1 \\
\hline
\end{tabular}

* Correlation is significant at 0.05

** Correlation is significant at 0.01

Source: Survey 2017

\subsection{Multiple Regression Analysis}

For this study one dependent and five independent variables were used. To identify the impact of independent variables on dependent variable the researcher used multiple regression analysis method. The stepwise regression method is used to determine the combination of possible independent variables that best explains the dependent variables (Argyrous2005).

Dependent variable in this study is Entrepreneurial intentions of TVET students. In order to select dependent variable the researcher calculated correlation coefficient between each independent variables and dependent variable. Accordingly the dependent variable which has high correlation with independent variables was students' preference to run their own business rather than participating in a lower-risk business after training completion.

Table: 4.7: Model Summary

\begin{tabular}{ccccc}
\hline \hline Model & $\mathrm{R}$ & R Square & $\begin{array}{c}\text { Adjusted } \\
\text { R Square }\end{array}$ & $\begin{array}{c}\text { Std. Error of the } \\
\text { Estimate }\end{array}$ \\
\hline \hline $\mathbf{1}$ & $.887^{\mathrm{a}}$ & .786 & .783 & 1.156 \\
\hline \hline
\end{tabular}

a. Predictors: (Constant), Administration Factor, Social Factor, Educational Factor, Financial Factor, Personality Trait Factor

b. Dependent Variable: Entrepreneurial Intention

The analysis of the results of the model depicted an $\mathrm{R}$ value of $.887, \mathrm{R}$ square of .786 and an adjusted $\mathrm{R}$ square value of .783; this means that the accuracy of the model is $78.3 \%$ and the variations in entrepreneurial intention can be explained by the explanatory variables up to $78.3 \%$. In addition to this, the model indicates a $\mathrm{P}$ value of 0.000 , which is significant. $(<0.05)$. This means that the regression model is adequate with the collected data and the variables are statistically significant at 5\% and these findings show that the challenges identified in this study affect the entrepreneurial intention of Tercha industrial college students up to $78.3 \%$ as indicated by the adjusted $\mathrm{R}$ square.

\subsection{Coefficients Analysis}

Table 4.8:-Multiple regression analysis for variables predicting students' entrepreneurial intentions after their training completion.

\begin{tabular}{|c|c|c|c|c|c|c|c|c|c|c|}
\hline \multirow{2}{*}{\multicolumn{2}{|c|}{ Model }} & \multicolumn{2}{|c|}{$\begin{array}{l}\text { Unstandardized } \\
\text { coefficients }\end{array}$} & \multirow{2}{*}{ 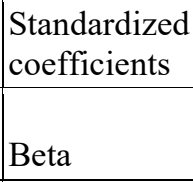 } & \multirow[b]{2}{*}{$\mathrm{T}$} & \multirow[b]{2}{*}{ Sig. } & \multicolumn{2}{|c|}{$\begin{array}{l}95 \% \text { confidence } \\
\text { interval for } b\end{array}$} & \multicolumn{2}{|c|}{$\begin{array}{l}\text { collinearity } \\
\text { statistics }\end{array}$} \\
\hline & & B & $\begin{array}{l}\text { Std. } \\
\text { Error }\end{array}$ & & & & $\begin{array}{l}\text { Lower } \\
\text { bound }\end{array}$ & $\begin{array}{l}\text { Upper } \\
\text { bound }\end{array}$ & Tolerance & VIF \\
\hline \multirow[t]{6}{*}{1} & (constant) & 1.352 & .529 & & 2.557 & .011 & .312 & 2.392 & & \\
\hline & Personality Trait & -.204 & .014 & -.442 & -14.194 & .000 & .176 & .233 & .656 & 1.525 \\
\hline & Social norm & .027 & .017 & .040 & 1.573 & .117 & -.007 & .060 & .978 & 1.023 \\
\hline & Educational & -.097 & .015 & -.216 & -6.366 & .000 & .067 & .127 & .553 & 1.809 \\
\hline & Access to finance & -.159 & .019 & -.334 & -8.167 & .000 & .121 & .197 & .381 & 2.624 \\
\hline & $\begin{array}{l}\text { government } \\
\text { Administration }\end{array}$ & -.038 & .017 & -.078 & 2.262 & -.024 & .005 & .071 & .533 & 1.875 \\
\hline
\end{tabular}

Dependent variable: entrepreneurial intention

Thus, the regression equation is:

$\mathrm{Y}=1.352-.204(\mathrm{PT})+.027(\mathrm{SN})-.097(\mathrm{ET})-.159(\mathrm{FA})-.038(\mathrm{GA})+\mathrm{e}$

Where $\mathrm{Y}=$ Entrepreneurial intention 
$\mathrm{PT}=$ Personality trait

$\mathrm{SN}=$ Social Norm

$\mathrm{ET}=$ Education and training

$\mathrm{FA}=$ Financial Access

$\mathrm{GA}=$ Government Administration

Based on the table above, the Standardized Beta coefficients indicate the contribution of each variable to the research.

The formula shows that the coefficient for personality trait is $-44.2 \%$ significantly and negatively affects the entrepreneurial intention of students with $\mathrm{p}$ value of .000 . This indicates a unit increase in personality trait, leads to a decrease in entrepreneurial intention by $-44.2 \%$ when all factors are held constant. This result indicates that the null hypothesis that personality trait does not affect the students entrepreneurial intention was rejected and the alternative hypothesis was accepted.

Looking at the P- value social norm does not appear to have a significant impact on the students' entrepreneurial intention patterns in Tercha industrial colleges. The finding goes against expectations. This result indicates that failing to reject the null hypothesis.

Education and training is significantly and negatively affects the entrepreneurial intention of college students with standardized beta value of $-26.1 \%$. It can be interpreted one unit increments in education and training results in an average decrease of $-26.1 \%$ the students' intention in formulation of their own business when other challenges were remaining as constant.

Financial access related challenges found to be significantly and negatively exerting an effect at 5\% significant level on the entrepreneurial intention of students by hindering with standardized beta value of -0.334 . This result explain as a unit increase in financial challenges lead to decrease the formation of their own business as well as entrepreneurial intentions by $33.4 \%$ when all other independent variables at zero. This implies that the null hypothesis was rejected with statistical evidence of the model basis.

It was found that there is a statistically significant and positive relationship between government administrations to students' entrepreneurial intentions. In other word the government administrations were negatively affects intentions by $-7.8 \%$.

\section{CONCLUSION}

The result of econometrics model indicated that the entrepreneurial intention of the students is significantly and negatively affected by personality trait, access to finance, education and training and government administration related factors except to social norms.

\section{RECOMMENDATION}

The intervention of students' entrepreneurs is to improve the living standards and reduces poverty. As such it improves the economic status of the society and country as a whole. Based on the study findings and conclusions drawn, the researcher forwards the following recommendations.

To Government and Policy makers

$>$ The ministry of education or the FDRE TVET Agency should design entrepreneurship education at early levels of TVET program to provide entrepreneurship education, to increase awareness of trainees about entrepreneurship, shaping their attitude toward the behavior and enhancing their perceived behavioral control and personality traits.

$>$ The researcher would like to advise curriculum designers, the industry (stake holders) that develops EOS to train on each level of TVET training and also included in each occupation. To TVET Colleges

$>$ The TVET Colleges should organize more entrepreneurial-related activities and workshops that can enhance activities or programs and workshops that can enhance students' perceived behavioral control, for instance, projects like business proposal, managing small business in colleges, providing opportunities for trainees to involve in managing their own business and get prior business experience.

$>$ The TVET Colleges should establish entrepreneurship center or demonstration room which can help the students to develop entrepreneurial skills and which enhancing the entrepreneurship course structure, subjects offering as to be proactive enough and practical-oriented with the aim of sustaining trainees' interest in entrepreneurship.

\section{Direction for Future Researchers}

The current study was based on small sample size taken from only five department students of Tercha industrial Colleges in Dawro Zone. Therefore, the results cannot be generalized to other TVET Colleges in Ethiopia especially in the analytical terms. Further research done on issues at large scale sample size could shed light on how entrepreneurial intentions of TVET students of the Ethiopian TVET systems are affected. 


\section{Reference}

Andualem T. (1997), Small Enterprise and Entrepreneurship Development in Ethiopia: Concepts, Definitions and Major Issues.

Bandura, A. (1977) Social Learning Theory, Prentice Hall, Englewood Cliffs, NJ.

Bandura, A. (1986). Social foundations of thought and action. Englewood Cliffs: Prentice Hall.

Gebrehiot A. and Wolday A.,(2004), Survey report on Micro and Small Enterprise Development in Ethiopia

Iacobucci, D., \& Micozzi, A. (2012). Entrepreneurship education in Italian universities: trends, Journal of Business Venturing, 15, 5-6, 411-432. Journal of Business Venturing, 21, 866-885.

Kirby, D.A. (2003) Entrepreneurship, McGraw Hill, Berkshire, UK.

Kirzner, I. (1979) Perception, opportunity and profit. Chicago. University of Chicago Press.

Knight, F.H. (1921) Risk, uncertainty and profit, Washington, DC: Beard Books.

Kolvereid, L. and Isaksen, E. (2006) New business start-up and subsequent entry into selfemployment.

Krueger, N., Reilly, M., and Carsrud, A. (2000) Competing models of entrepreneurial intentions.

Kuratko, D. (2005) The emergence of entrepreneurship education: Development, trends, and

Menzies, T., \& Paradi, J. (2003). Entrepreneurship education and engineering students: career path and business performance. Entrepreneurship and Education(May), 121-132.

Nabi, G., \& Holden, R. (2008). Graduate entrepreneurship: intentions, education and training.

Packham, G., Jones, P., Pickernell, D., \& Brychan, T. (2010). Attitudes towards entrepreneurship

situation and opportunities. Education Training, 54(8/9), 673-696. 